\title{
Hostes humani generis: Pirates, Slavers, and Other Criminals a
}

Joaquín Alcaide Fernández

The Oxford Handbook of the History of International Law

Edited by Bardo Fassbender and Anne Peters

Print Publication Date: Nov 2012 Subject: Law, History of Law, International Law

Online Publication Date: Dec 2012 DOI: 10.1093/law/9780199599752.003.0006

\section{Abstract and Keywords}

This chapter notes that legal literature and States have built upon Cicero's legacy of pirates as hostes humani generis, extending to other acts the legal consequences attached to them (criminalization and universal jurisdiction): slave-trade or enslavement, war crimes, crimes against peace, crimes against humanity, and terrorism. Piracy, slavery, and other acts or activities that are nowadays considered criminal were not necessarily in other times. The theoretical distinction between piracy and privateering blurred in practice. International law provided arguments and legal foundations to address the repression of pirates, slavers, and other criminals before 1945; yet law-enforcement practice also offered arguments to prevent their criminal prosecution on a universal jurisdiction basis.

Keywords: piracy, slavery, Cicero, criminalization, international law, war crimes, terrorism

\section{Introduction}

Despite Cicero's celebrated definition of pirates as hostes humani generis, ${ }^{1}$ there is no trace of the expression in (positive) international law. The 'criminals against humanity'which included enslavers and sexual slavers, ${ }^{2}$ but not (yet) pirates or terrorists-come the closest today to those 'enemies of all humanity'. There being no mention on international treaties, what is it that scholars have meant when they referred to hostes humani generis in treatises on international law? The meaning was generally twofold: (p.121) pirates were worthy of punishment; and, to put it plainly as did Grotius, any pirate 'is justiciable by any State anywhere'. ${ }^{3}$

Concerning the historical legal foundations in accordance with which pirates, slavers, and others might be considered as (international) criminals, there are several questions. Since when can it be affirmed that they were such criminals? Was prohibition equal to criminalization? Provided that legality is a principle of international law-it might not have been so before $1945,{ }^{4}$ although the principle nullum crimen, nulla poena sine lege was soon recognized afterwards in human rights law-even 'any' generally accepted defi- 


\section{Hostes humani generis: Pirates, Slavers, and Other Criminals}

nition does not satisfy the requirement of specificity. Perhaps the Nuremberg trials were not the only exception aiming for substantive justice at the expense of strict legality. Further questions which may be posed include: were these criminals subject to universal jurisdiction? And last but not least, was every State eventually bound to prosecute?

The responses always depend upon the theory ('positivist' or 'naturalist') one adheres to relating to the foundation, nature, and scope of (criminal) international law. As the international law of piracy has not been universally codified (or progressively developed) until 1958 , it is necessary to rely on practice and to identify the 'proper' law under consideration, be it municipal or international law. States and their mentioned municipal courts whose findings were supposedly based on 'the law of nations' have frequently used antipiracy municipal laws as international law; municipal assertions of law have been received as persuasive statements of true international law.

For a long time, there had been no 'international' means of capturing, trying, or punishing criminals. Not a single proposal-either governmental or non-governmental-to create a criminal international court was successful before 1945. Although international law might have defined the elements of the crime (mens rea, actus reus, and locus), the recognition of the acts as constituting crimes, and the trial and punishment, were left by international customs or treaties to the municipal law and courts. Some scholars state that while piracy ${ }^{5}$ or slave trade, or enslavement, ${ }^{6}$ for instance, might have been crimes under municipal law, they were not crimes against international law, but only constituted a special basis of States' jurisdiction, otherwise restricted to crimes committed on its territory or by its nationals. States were then not obliged to prosecute and punish these criminals. It has (p. 122) been mainly since 1945-especially after the Cold War-when international law admitted individual criminal responsibility, both at the municipal and at the international level. This led to the International Criminal Court (ICC). Scholars still debate whether or not the duties set forth to bring criminals to justice at the municipal level fall within the realm of what is today criminal international law. Most criminals will usually be prosecuted and punished according to international law by any State which happens to seize them, as even the ICC is only complementary to national criminal jurisdiction.

The interrelationships between the criminal acts and the legal responses should be highlighted. Firstly, war crimes and crimes against humanity might encompass otherwise discrete crimes (enslavement, terrorism, torture, etc.). Pirates did not renounce 'man stealing', and even privateers did not merely take captives, but sold them as slaves and interfered with the slave trade. ${ }^{7}$ Pirates/privateers became slavers, and vice versa.

Secondly, willing to establish criminalization and universal jurisdiction, some Statesnamely the United Kingdom and the United States-were prone to equate slave trade at sea to piracy (the 'piracy analogy'). British attempts go back to the 1822 Congress of Verona and only reached a conclusion with the codification of the law of the sea. ${ }^{8} \mathrm{By}$ 1882, a network of more than fifty bilateral agreements permitted the search of suspected slave vessels on the high seas, without regard to their flag. Precisely in connection to 


\section{Hostes humani generis: Pirates, Slavers, and Other Criminals}

British arrests of foreign vessels engaged in the slave-trade, the freedom of the (high) sea(s) gained general acceptance as it was formulated by English and American courts early in the 19th century, ${ }^{9}$ once piracy had declined. Even a treaty for the abolition of the slave trade was held not to justify the arrest of a vessel of the other party, unless the treaty specifically conferred that right upon the contracting States. ${ }^{10}$ And the treaty can be interpreted as an acceptance of limits to the exercise of jurisdiction whose extension had been previously generally accepted. ${ }^{11}$ Some treaties also compared the violation of the laws of war to piracy (with the clause 'as if for an act of piracy'). ${ }^{12}$ The same comparison has been used decades later when acts against the security of (civil) aviation have been called 'aerial piracy' in legal literature and municipal law, ${ }^{13}$ and recently, acts against the (p. 123) safety of maritime navigation or the taking of hostages at sea have been treated as piracy. ${ }^{14}$

\section{Piracy}

Piracy is much older than maritime navigation, although its rise in modern times was connected to the increase of trade with the Indies and of privateering-that is, private vessels acting under a commission ('letter of marque and reprisal') issued by a State to capture vessels of an enemy State, and neutral States trading with it, giving to the privateer the prizes taken, with the exception of a percentage to the Crown, and providing for the speedy adjudication of claims. ${ }^{15}$

The legal recognition of pirates as criminals emerged from centuries of intermittent cooperation and conflict between States and privateers, involved in piracy-like acts, as the difference between privateering and piracy was usually blurred in practice. Furthermore, it has been said that many States, by not inserting in their municipal law provisions for prosecuting and punishing piracy in all circumstances even when committed by foreigners outside the State's ordinary jurisdiction, simply assumed piracy to constitute a special basis of State's jurisdiction. It is certainly difficult to find cases of an exercise of jurisdiction over piracy which could not be supported on one or more of the usual grounds.

\subsection{Towards an Absolute Prohibition of Piracy}

Modern international law did not outlaw piracy absolutely (privateering included) at least until the second half of the 19 th century. ${ }^{16}$ Even then, this can be determined only by indirect references to piracy in international negotiations and treaties.

\section{(p. 124) 2.1.1. Cooperation and Conflict between States and Private Vessels: Privateers versus Pirates}

States began the prohibition of piracy long ago. There were a number of piracy trials before municipal courts. The trial $R v$ Joseph Dawson before the High Court of Admiralty, and the charge that Sir Charles Hedges submitted to the grand jury in $1696,{ }^{17}$ or the case United States $v$ Smith in $1820,{ }^{18}$ are all examples. It might follow from that, that piracy 


\section{Hostes humani generis: Pirates, Slavers, and Other Criminals}

may be considered as a violation of international law, and perhaps subject to the (criminal) ${ }^{19}$ jurisdiction of all States.

Notwithstanding, modern States soon discovered the benefits of using privateers as adjuncts of the State's armed forces (even preceding royal navies) and, as a sign of the building of modern States, accepted licensing privateers as a prerogative of recognized States-and only of States, as was the case with resorting to war. As early as the end of the 13th century, municipal laws often authorized privateering; amongst other municipal or international legal criteria (such as validity of the commission, nationality of the captured vessel or its cargo, bonds furnished, respect of the temporal and material constraints of the commission, having no commissions from more than one sovereign, etc.), the commission was necessary to prevent the privateers from being treated as pirates (who, at best, governed themselves by the so-called pirate articles, mainly based on terror, fear, etc.). These regulations can be traced from the Pisa (1298) and Geneva (131316) laws, Pedro IV of Aragon's Ordinance of 1356, the Laws of the Hanseatic League (1362-64), Charles V of France's Ordinance of 1373, the seminal prize court regulation in English Parliamentary Act of 1414, etc., to the French Ordinance of 1778 or the Spanish Ordinance of 1801, and additions.

But differentiation between pirates and privateers was subtle in practice. From the 16th century onwards, cooperation and conflict between States and privateers were dependent upon the (un)friendly relationships between old European States; namely, England, France, and Spain, but also the Netherlands, hence the centrality of privateering in Grotius' or Bynkershoek's writings. The perceptions about the status of the private vessels differed, so piracy was not the same for each and every State everywhere and every time. History and the romantic imagination have been filled with heroes and villains (the Vikings, Barbary pirates and privateers, Sir Francis Drake, Edward Teach called 'Blackbeard', etc.), somehow anticipating the political exemption problem in the fight against terrorism in the 20th century, which permitted States not to extradite terrorists because their actions were considered political offences rather than common offences.

English and Spanish legislative practices are examples of this cooperation and conflict. For instance, Henry VIII (English Offences at Sea Act 1536) and Elizabeth I (p. 125) (Proclamations of 1569 or 1575) outlawed pirates while authorizing privateers against Spanish trade. After the accession of James I and the end of the Spanish wars (1604), new anti-piracy acts were declared and commissions revoked. At the end of the wars between England and Spain (1692) and 'King William's War' (Treaty of Ryswick), England revoked the licences of its privateers (Piracy Acts of 1698). But during the War of the Spanish Succession (1702-13) England attacked the Spanish monopoly of commerce in the 'South Sea', where Spain had made it piracy for any but a Spanish vessel to trade there (English Act of 1707).

After the Peace of Utrecht (1713), the so-called 'Golden Age of Piracy' declined due to one essential factor: piracy was the victim of its own success. Excess of trained sailors without employment or rebels against the established order-many of them former priva- 


\section{Hostes humani generis: Pirates, Slavers, and Other Criminals}

teers-had become pirates who damaged and threatened all trade every where, and without distinction amongst nations. More than ever before, piracy was considered an act of savagery by Western States (for instance, English acts of 1717, 1721, 1744, and 1837), so it was only accepted as 'reasonable' if committed by 'savages'-even though sponsored by Western States. The next step forward was to recover the definition of pirates as 'enemies of all humanity', while tolerance for privateers was wearing thin by all nations.

\subsubsection{The 1856 Declaration: The Abolition of Privateering}

When some municipal laws were eventually adopted to prohibit privateering, and when commissions were revoked (for example, by the Royal Pragmatic issued in 1498 by Fernando 'the Catholic', King of Aragon), several international treaties and practices prohibited privateering as well. England and France did so many times, starting with the diplomatic overtures of Edward III in 1324, and a number of unilateral and bilateral declarations limiting privateering between 1785 and 1823, but none remained in force after a war broke out between the parties involved.

From a French proposal, the Declaration (actually a treaty) Respecting Maritime Law was signed in Paris, in 1856. ${ }^{20}$ According to the Declaration, '[p]rivateering is, and remains, abolished'. None of the States parties could authorize as privateering the acts which otherwise would be considered piracy; however, once captured, privateers commissioned by third States were still to be treated as prisoners of war. Other States acceded later to the Declaration (for example, Spain in 1908, but not the United States). ${ }^{21}$ Privateering begun to fall into disuse, and its abolition began to gain 'objective' authority. For example, a number of resolutions of the Institute of International Law affirmed that privateering was forbidden: if not the 'Rules of Washington' (1875), at least the Resolutions of Zurich (1877), Turin (1882), and Oxford (1913).

(p. 126) Only under exceptional conditions could a private vessel converted into a war-ship have the rights and duties accruing to such vessels. The 1907 VII Convention ${ }^{22}$ codified, and resolutions of the Institute of International Law reaffirmed, ${ }^{23}$ the State practice (Prussia in 1870, Russia in 1877, the United Kingdom in 1887, France, Germany, United States, etc.) which indicated that those vessels should be placed under the direct authority, immediate control, and responsibility of the power whose flag they flew.

\subsubsection{The Clause 'As if for an Act of Piracy'}

Piracy and privateering also formed the background to other treaties. Although never entered into force because France failed to ratify, it is worth noting that signatory powers of the 1922 Treaty of Washington relating to the Use of Submarines and Noxious Gases in Warfare ${ }^{24}$ stated that

any person in the service of any Power who shall violate any of [the rules set forth in article 1] ... shall be deemed to have violated the laws of war and shall be liable to trial and punishment as if for an act of piracy and may be brought to trial be- 
fore the civil or military authorities of any Power within the jurisdiction of which he may be found.

Furthermore, on 14 September 1937, during the Spanish civil war, representatives of several States signed at Nyon an accord for the purpose of denouncing the attacks by submarines against merchant ships not belonging to either of the conflicting Spanish parties $^{25}$ as violations of 'the established rules of international law'. Even though neither the clause 'as if for an act of piracy', nor the term 'piracy', are used in either of those 'established rules', the 'anti-piracy agreements' of 1937 declared that the said attacks are 'contrary to the most elementary dictates of humanity, which should be justly treated as acts of piracy'. The parties to the accord agreed as well to special collective measures 'against piratical acts by submarines' (or surface vessels or aircraft, according to a supplementary agreement signed three days later at Geneva, 17 September, by the same powers). ${ }^{26}$ These agreements contained no provisions for the punishment of the officers and crews of offending vessels or craft as pirates who were caught committing 'piratical acts'. The legal basis for declaring those attacks in the Mediterranean to be acts of piracy seems to be the lack of recognition of belligerency (p. 127) of the (thus simply insurgent) parties to the conflict in Spain. ${ }^{27}$ In its protests to Germany during the World Wars, the United States applied also the term 'piracy' to the acts of German submarines against merchant vessels.

\subsubsection{Piracy and the League of Nations}

During the era of the League of Nations ( $\mathrm{LoN})$, an attempt was made to provide a general agreement on piracy. Following the Assembly resolution of 1924, the League appointed a sub-committee of its Committee of Experts for the Progressive Codification of International Law. In the 'Matsuda report', the sub-committee stated that 'according to international law, piracy consists in sailing the seas for private ends without authorization from the government of any State with the object of committing depredations upon property or acts of violence against persons'. The definition did not deal with an armed rising of the crew or passengers with the object of seizing the ship on the high sea. ${ }^{28}$ The so-called questionnaire on piracy (consisting of the 'Matsuda report' and Matsuda's draft provisions for the suppression of piracy) was submitted to a number of States, ${ }^{29}$ but some of them did not acknowledge the desirability/possibility of a convention on the question. Some commentators criticized the report itself and even the transmission of the report to States because of 'the present immature stage' not of the subject in itself, but of the report. 30

The League's efforts fizzled out, and the subject was dropped from any conference for two reasons: piracy seemed not to be an urgent problem, and it was not likely that an agreement would be reached. 


\subsection{The Anti-piracy International Legal Regime around 1945: A Brief Overview}

A sort of syllogism may help to overcome the confusion regarding the international law of piracy. There is no doubt that the provisions enshrined in the 1958 (p. 128) Convention on the High Seas ${ }^{31}$ were based on the ILC's draft convention and later inserted in the 1982 UNCLOS. ${ }^{32}$ For its part, apparently the ILC closely followed the research carried out at the Harvard Law School which had culminated in a draft convention prepared in 1932 (indeed, all provisions contained in the rapporteur François' draft, adopted as the ILC draft, were a French translation of the Harvard Draft Convention on Piracy). ${ }^{33}$ Finally, although it is not unanimously accepted that the 1958 Convention strictly 'codified' the traditional international law of piracy, there is widespread agreement that, although it still raised difficulties, the piracy rules contained in the UNCLOS reflect customary international law. The Harvard Draft Convention has been used by some scholars to discuss the history and development of that international law of piracy 'as it developed over many centuries'. ${ }^{34} \mathrm{I}$ will refer briefly to the definition of piracy and the jurisdiction over pirates, leaving aside matters such as property rights ('pirata non mutat dominium', etc.).

\subsubsection{The Definition of Piracy: International Law and Municipal Law}

Over the centuries, there was no authoritative definition of piracy in general international law. Acts that are piratical under municipal law ${ }^{35}$ may not be so under international law (for example, in English criminal law it has been piracy to engage in slave trading). Although the lack of adjudication and of pertinent instances of State practice occasioned some confusion among experts as to what international law includes, or should include, in the definition of piracy, it seemed to be accepted that it was 'of the essence of a pirate act to be an act of violence, committed at sea or at any rate closely connected with the sea, by persons not acting under proper authority'. ${ }^{36}$ There has been and there still is debate about other elements-other than the choate or inchoate criminality ${ }^{37}$ - such as the purpose (robbery or private ends versus (p.129) political ends) ${ }^{38}$ and the place (acts committed outside all territorial jurisdiction, but not on the high seas). ${ }^{39}$

After the 1856 Declaration, it was generally accepted that the proposition according to which pirates may be lawfully captured on the (high) seas by armed vessels of any State and brought within its territorial jurisdiction for trial before its municipal courts, should 'be confined to piracy as defined by the law of nations, and [could not] be extended to offences which [were] made piracy by municipal legislation' ${ }^{40}$

\subsubsection{Universal Jurisdiction}

Because piracy had to occur outside the municipal jurisdiction of any nation, it has been considered as a, if not the, quintessential crime subject to universal jurisdiction. Although this conclusion has been contested, ${ }^{41}$ it appears, for instance, from the published records of the conference where the provision 'punishment as if for an act of piracy' was inserted in the 1922 Treaty of Washington. The representatives assented to the following proposition as one of the core provisions of the treaty: under that provision, the offender would not be subject to the limitations of territorial jurisdiction, the peculiarity about the pun- 


\section{Hostes humani generis: Pirates, Slavers, and Other Criminals}

ishment for piracy being that, although the act is done on the high seas and not within the jurisdiction of any country, nevertheless it can be punished in any country where the offender is found. ${ }^{42}$

Accordingly, every State might (or must) ${ }^{43}$ seize a pirate ship (later a pirate aircraft as well), or a ship taken by piracy and under the control of pirates, and arrest the persons and seize the property on board, pending the seizing State's court decision upon the penalties and the action to be taken with regard to the ships (or aircraft) and property. ${ }^{44}$ The seizure should only be carried out by warships (or, afterwards, by military aircraft), or other ships (or aircraft) on government service authorized to that effect ${ }^{45}$ (for instance, a French law enacted in 1825 authorized the merchant vessels to carry out the seizure).

It was generally (but not unanimously) accepted that the right of hot pursuit did not cease when the pirate ship pursued entered the territorial waters of a State other than the pursuing State, unless prohibited by the coastal State, ${ }^{46}$ the courts of which (p. 130) have, however, jurisdictional priority. There was also a provision on the liability of the pursuers or seizing State against damages to non-pirate ships or to other States, ${ }^{47}$ and a statement of the rights of persons accused of the crime. ${ }^{48}$

\section{Slavers}

Throughout the ages, different societies and civilizations have considered slavery as a 'natural' state or a fair penalty, but almost always some thought of it as morally reprehensible. ${ }^{49}$ The method of enslavement was sometimes considered legal, in other times illegal. From the 16th century onwards, when the numbers alone exceeded any past practice, the native Africans ('Negroes') were the main victims, but in earlier times no race was exempt or 'unenslavable'. Both enslavement and slave trade were very profitable branches of commerce, offering widespread economic benefit, and-in contrast to piracy - slavery was legal in most countries of the world.

At dawn of the 19th century, when European empires were trafficking with 'Negroes', technical and economic circumstances changed-because the decline of the relevance of manpower-as moral and religious circumstances did, mainly under the direction of the Church of England, followed by the Pope's instructions, and the abolitionist movement, which gained strength after the famous case of James Somerset (1772), ${ }^{50}$ and drew moral and intellectual inspiration from the general proclamations of human rights. Even Haiti became independent in 1804 after a slave revolt. These were the days when Britain wanted rival colonial and maritime powers to join its 'crusade' against the slave trade so as to prevent trade and manpower-power itself-from passing to rivals hands. ${ }^{51}$

International cooperation began openly in 1814-15, mainly occupied with African slave trade, but the abolition of the slave trade did not entail immediately the prohibition of ownership of slaves. The British Slavery Abolition Act was passed in 1833, and emancipation spread throughout most new independent Latin American States, to France in 1848 


\section{Hostes humani generis: Pirates, Slavers, and Other Criminals}

and to the United States in 1863. Firstly the enslavement and slavery-related practices were prohibited in the laws and customs of war, yet the different legal status of the slave trade and slavery is still evident in article 2 of the 1926 Slavery (p. 131) Convention. ${ }^{52}$ Furthermore, as piracy provisions, the prohibition of the slave trade transformed the law of the sea in itself-the 1958 Convention on the High Seas (article 13) and the 1982 UNCLOS (article 99). However, as opposed to the anti-piracy regime, here there is no recognition of universal jurisdiction. The 1926 Convention was supplemented in 1956, when other main steps forward had been, or were about to be, taken (articles 1.3, 55 and 56 of the UN Charter; articles 1, 3, 4, 5, and 6 of the UDHR; articles 8 and 15 of the 1966 ICCPR; obiter dictum in the 1970 judgment of the ICJ; etc.). It should be noted however that it is difficult not only to determine when the slave trade and enslavement became a violation of customary international law, ${ }^{53}$ but also to find anyone tried before criminal courts for slave-trading or enslaving before 1945.

\subsection{The Abolition of African Slave Trade and the Woman and Chil- dren Traffic}

In 1807, US Congress passed the Act to Prohibit the Importation of Slaves, renewed between 1818 and 1820, as the British Parliament adopted the Act for the Abolition of the Slave-Trade, revised in 1824, 1843, and 1873. A number of declarations and international treaties were then designed to abolish first the African slave trade (once the Atlantic trade had declined in the last third of 19th century, there was still an active trade from Africa to the Muslim World), then the white-slave trade, trade in women, and child trafficking.

\subsubsection{The Congress of Vienna (1815) and the Treaty of London (1841)}

The first international instrument to deal specifically with the slave trade in general was the 1815 Declaration Relative to the Universal Abolition of the Slave-Trade (the 'Eight Power Declaration'), signed in Vienna on 8 February $1815 .{ }^{54}$ The Declaration acknowledged that the slave trade was 'repugnant to the principles of humanity and universal morality', but did not contain provisions to enforce a duty (p. 132) to prohibit, less criminalize, it. Elsewhere it was declared to be condemned by 'the laws of religion and nature' (treaty signed on 20 November 1815 among Austria, France, Great Britain, Prussia, and Russia), whereas the Treaty of Peace and Amity, signed in Ghent, 18 February 1815 by United States and Great Britain, had declared that the slave trade was 'irreconcilable with the principles of humanity and justice' ${ }^{55}$

Most of the signatories of the 1815 Declaration-which a few years later reaffirmed their opposition to the slave trade and their intention to its abolition in the Declaration Respecting the Abolition of the Slave Trade, 28 November $1822^{56}$-signed in London, on 20 December 1841, the Treaty for the Suppression of the African Slave-Trade. ${ }^{57}$ The object and purpose were to give full and complete effect to the principles of the 1815 Declaration, deeming the slave trade equal to piracy and enshrining not just duties to prohibit, 
Hostes humani generis: Pirates, Slavers, and Other Criminals

prevent, prosecute, and punish, ${ }^{58}$ and establish a criminal jurisdictional basis, ${ }^{59}$ but also to cooperate, including through judicial assistance. ${ }^{60}$

\subsubsection{The General Acts of Berlin (1885) and Brussels (1890) Conferences and their 1919 Revision}

The Declaration Concerning the Slave Trade and the Operations Which on Land or Sea Furnish Slaves to the Trade, discussed and adopted during the Conference of Berlin, and attached to the General Act signed on 26 February 1885, joined new States to those which were parties to the 1815 Declaration, including the United States. ${ }^{61}$ This Declaration recognized that the slave trade was prohibited in accordance with the principles of the law of nations', and the Powers exercising sovereignty or influence in the Congo Basin engaged 'to use all means at its disposal to put an end to this trade and to punish those engaging in it'. ${ }^{62}$ Another declaration contained the engagement of these Powers to strive for the suppression of slavery and especially of the slave trade. ${ }^{63}$

Five years later, during the 1889-90 Brussels Conference, a comprehensive international treaty against the slave trade in Africa was adopted. ${ }^{64}$ The parties to the General Act signed on 2 July declared to be inspired by 'the firm intention of putting an end to the crimes and devastations engendered by the traffic in African slaves', and the wish (p. 133)

to give fresh sanction to the decisions already adopted in the same sense and at different times by the powers, to complete the results secured by them, and to draw up a body of measures guaranteeing the accomplishment of the work which is the object of their common solicitude.

Yet the General Act also served the powers' territorial and commercial ambitions. It enshrined humanitarian provisions such as measures to be taken in the places of origin; provisions concerning caravan routes and transportation of slaves by land; the repression of the slave trade at sea (including a right to visit, search and detain vessels, and the provision according to which any slave who takes refuge on board any vessel of a State signatory shall be immediately and definitively set free); or duties of countries to which slaves are sent. Therefore, signatory States established obligations to repress the slave trade on land and sea. For the first time in history, a treaty-monitoring body was established, the International Maritime Office, based in Brussels and Zanzibar, for the exchange of information on slave-trade and anti-slavery municipal laws.

However, because of the commercial restrictions posed by the Brussels General Act, the colonial powers had no desire to renew it after the First World War and substituted it by a clause inserted into the Convention Revising the Berlin and Brussels Acts, signed on 10 September 1919, at Saint-Germain-en-Laye, ${ }^{65}$ which in fact abrogated those acts concerning the slave trade for those States that ratified it. Yet according with the 1919 Convention, the Powers exercising sovereignty in African territories affirmed their intention to 'endeavour to secure the complete suppression of slavery in all its forms and of the slave trade by land and sea'. ${ }^{6}$ 


\subsubsection{White Slave Trade and Traffic in Women and Children: The 1904, 1910, 1921, and 1933 International Conventions}

The suppression of the white-slave trade was the object and purpose of both the 18 May 1904 International Agreement, ${ }^{67}$ and of the 4 May 1910 International Convention and Final Protocol, ${ }^{68}$ signed in Paris. The first established the cooperation in the prosecution and punishment of that traffic, including judicial assistance; ${ }^{69}$ the second contained 'minimum' provisions to prohibit, prevent, prosecute, and punish the proscribed practice-including cooperation through judicial assistance concerning the transmission of Letters of Request and the communication of records of (p. 134) convictions ${ }^{70}$-to extradite the (presumably) responsible, and to establish a criminal jurisdictional basis. ${ }^{71}$

Furthermore, the parties to the International Convention for the Suppression of the Traffic in Women and Children, signed in Geneva on 30 September 1921,72 agreed to take all measures to discover and prosecute, and secure the punishment of, or to extradite, persons who are engaged in the traffic in children of both sexes and who committed offences within the meaning of the 1910 Convention. ${ }^{73}$ This Convention was followed by the International Convention for the Suppression of the Traffic in Women of Full Age, signed in Geneva on 11 October $1933,{ }^{74}$ which enshrined the duties to prohibit, prosecute, punish, and to cooperate therein. ${ }^{75}$

All these conventions were amended in $1947^{76}$ or $1949^{77}$ to enable the UN to perform all duties in place of the LoN, and the 1950 Convention for the Suppression of Traffic in Persons and of the Exploitation of the Prostitution of Others ${ }^{78}$ supersedes them in the relations between parties thereto.

\subsection{The 1926 League of Nations' Slavery Convention and Subsequent Developments}

By appointing in 1924 a Temporary Slavery Commission (TSC)—with Albrecht Gohr as Chairman-the LoN ended up shifting from monitoring to making the international law on the suppression of the slave trade and slavery, devising a general convention-beyond article 23 of the Covenant and against all predictions, because there was no enthusiasm from any State, not even from Britain, and some (p. 135) open reluctance, for example from the Portuguese delegate. The International Convention with the Object of Securing the Abolition of Slavery and the Slave Trade, signed in Geneva, on 25 September 1926, ${ }^{79}$ was ultimately inspired by Sir Frederick Lugard, British member of the TSC, through the provisions officially proposed by the United Kingdom. The LoN Assembly's resolution recommending for approval the annexed draft convention was adopted on the proposal of Viscount Cecil of Chelwood, the British delegate to the League.

The parties to the 1926 Convention went on to differentiate two international legal regimes, one on the slave trade, the other on slavery, as they undertake 'to prevent and suppress the slave trade', and 'to bring about, progressively and as soon as possible, the complete abolition of slavery in all its forms' ${ }^{80}$ The formulation of the duty relating to slavery composed in 1926 had many positive elements: it must be a 'complete abolition' 


\section{Hostes humani generis: Pirates, Slavers, and Other Criminals}

and 'in all its forms'. But, despite the duty to secure the complete suppression of slavery in all its forms seemingly set out at Saint-Germain-en-Laye in 1919, there were also negative elements: the abolition might be brought about only 'progressively and as soon as possible'. The drafters within the LoN were too cautious in seeking to gain the acceptance of provisions on penalizing violations of the proposed Convention. Notwithstanding, the parties undertook to give one another every assistance with the object of securing both the abolition of slavery and the slave trade; ${ }^{81}$ when necessary, to adopt the necessary measures so that severe penalties may be imposed in respect of infractions of laws and regulations enacted both to prevent and suppress slave trade and to abolish slavery; ${ }^{82}$ and to communicate any these laws and regulations. The Convention contains no other mechanism of enforcement, although the LoN would establish a Committee of Experts on Slavery, later Advisory Committee on Slavery. ${ }^{83}$

The Convention enshrined the definitions of both slavery and the slave trade. ${ }^{84}$ It also referred to an apparently different but related practice: forced or compulsory labour. ${ }^{85}$ Being the most debated provision during the drafting process, article 5 on forced labour when used for private ends was rather limited in 1926. On 28 June 1930, the General Conference of the ILO adopted the Convention Concerning Forced and Compulsory Labour. ${ }^{86}$

(p. 136) Later, according to the 1956 UN Supplementary Convention on the Abolition of Slavery, the Slave Trade, and Institutions and Practices Similar to Slavery ${ }^{87}$, the States parties reinforced the criminalization of the slave trade, enslaving, and related practices, ${ }^{88}$ and undertook to adopt measures to abolish debt bondage, serfdom, forced marriage, and child exploitation. ${ }^{89}$ The status of these is not necessarily 'slavery', but defined as 'servile', 90 and other institutions and practices similar to slavery and the slave trade have been identified. ${ }^{91}$ Although the definition of slavery has not evolved since 1926 (1956 Convention ${ }^{92}$ and 1998 ICC Statute), ${ }^{93}$ its interpretation is contested. Furthermore, as new forms of slavery and slave-related, or similar practices have appeared, perhaps the definition might have proven too limited to cover all these new forms. The political and emotional significance of the 'label' slavery, and the legal force of the prohibition of slavery nowadays explain that some legal scholars propose to extend this definition to institutions and practices similar to slavery. ${ }^{94}$

The 1926 Convention continued with the 'civilizing mission', yet Western or mandatory powers sought to ensure that the Convention did not apply to their colonial or mandated territories. ${ }^{95}$ And twice during the drafting process, the United Kingdom sought to have the slave trade at sea assimilated to piracy. The other delegations did not agree-even though Britain would have been satisfied with a right to visit and search, and not to seize. According to the resulting article 3, the parties undertook to adopt all appropriate measures with a view to preventing and suppressing the embarkation, disembarkation, and transport of slaves simply 'in their territorial waters and upon vessels flying their respective flags'. The complementary general convention or special agreements due to be nego- 
tiated have never been negotiated or concluded, (p. 137) and the United Kingdom made a last attempt (again unsuccessfully) during the negotiations of the 1956 Convention. ${ }^{96}$

\subsection{The Enslavement and other Slavery-related Crimes in the Laws and Customs of War}

The regulation of the use of prisoners of war (POWs) for labour and the prohibition of any compulsion of the population of occupied territory to take part in military operations against its own country are dealt with in the 1899 Hague Convention (II) on the Law and Customs of War on Land and the Regulations annexed, adopted on 29 July, ${ }^{97}$ and the 1907 Hague Convention (IV) and the Regulations annexed, adopted on 18 October, which replaced the 1899 Hague Convention (II) and Regulations between States parties. ${ }^{98}$ There we find incorporated some protections for both civilians and belligerents from enslavement and forced labour in (international) armed conflict or in the situation of occupation. ${ }^{99}$ The respective chapter II of the 1899 and 1907 Regulations was complemented by the Geneva Convention Relating to the Treatment of Prisoners of War, adopted on 27 July $1929 .{ }^{100}$ Sometimes the protection offered to POWs was unilaterally extended to civilian enemy aliens in the territory of the belligerent. ${ }^{101}$

Besides the Charter of the [Nuremberg] International Military Tribunal, ${ }^{102}$ the 1899 and 1907 Regulations or the 1929 Convention were the legal foundation of the Nuremberg indictments on slave labour and enslavement as war crimes or crimes against humanity counts, although the laws and customs of war contained no rules regarding criminal responsibility (apart from the somewhat weak provision in article 30 of the Geneva Convention and other circumstantial evidence). ${ }^{103}$

(p. 138) Later on, the prohibition of slavery and the identification of slavery-related crimes were reaffirmed in subsequent codification and progressive developments on war crimes and crimes against humanity: the four 1949 Geneva Conventions and the two 1977 Protocols; ${ }^{104}$ the recognition that no statutory of limitation shall apply to slavery and related crimes; ${ }^{105}$ and the ICC Statute. ${ }^{106}$ In 1950, the ILC stated that those violations of the laws or customs of war constitute 'war crimes' or 'crimes against humanity'. ${ }^{107}$

Remarkably, in addition to the focus on human rights, the determination of slave-trading and enslaving as (international) crimes adds the perspective of individual criminal responsibility. Therefore the interpretation of the slave trade, slavery, and enslavement may differ from (a human rights) court to (a criminal) court. ${ }^{108}$

\section{Other Criminals}

There is some evidence that, according to international law up to 1945, war criminals and other war-related criminals, and perhaps terrorists (but, surprisingly, not torturers as such), might be defined as criminals. 


\section{Hostes humani generis: Pirates, Slavers, and Other Criminals}

\section{(p. 139) 4.1. War Criminals and Other War-related Criminals}

The rules defining acceptable behaviour in war are as old as war itself, and the trial of Peter von Hagenbach by an ad hoc tribunal of the Holy Roman Empire in Breisach (Germany), 1474, might be the first 'international' war crime (or crime against humanity) trial. ${ }^{109}$ Until recently, municipal laws of war addressed interstate wars (the Lieber Code during the US Civil War being a notable exception). International law followed this pattern when several instruments adopted in Geneva and Hague paved the way to modern war crimes (and crimes against humanity): the 1864 Geneva Convention for the Amelioration of the Condition of the Wounded in Armies in the Field, ${ }^{110}$ updated in 1906 and $1929,{ }^{111}$ but never complemented by the permanent international court proposed by Gustave Moynier in 1872; ${ }^{112}$ the 1899 and 1907 Hague Conventions, which embodied the 'Martens clause' and the principles of necessity, distinction, and proportionality; ${ }^{113}$ and the 1929 Geneva Convention on POWs. ${ }^{114}$

War crimes and war-related crimes against humanity and crimes against peace were not new in 1939-45. The Commission on the Responsibility of the Authors of the War and the Enforcement of Penalties, established in 1919, worked on three legal determinations: the responsibility of Kaiser Wilhelm II and his senior ministers for initiating a war of aggression in Europe; the violations of the laws and customs of war by Germany and its allies; and the prosecution of some Ottoman Empire officials for the deportation and massacre of its Armenian population-which had prompted the Allied governments of France, Great Britain, and Russia to issue on 24 May 1915 a joint declaration denouncing these acts as 'crimes against humanity and civilization' ${ }^{115}$ In a rather enigmatic manner, articles 227 to 330 of the Treaty of Versailles, signed on 28 June $1919,{ }^{116}$ were drawn up for the arrest and trial of German officials defined by the Allied governments as war criminals before an international court or (p. 140) Allied domestic courts. The Dutch government never handed over the former Kaiser; and, with Allied acceptance, several German military commanders were-reluctantly-tried from in 1921 by the German Supreme Court ('Leipzig War Crimes Trial').

New developments were to come before the outbreak of Second World War not only in the laws and customs of war (including, it may be recalled again, the circumstantial evidence offered by article 3 of the 1922 Treaty of Washington), ${ }^{117}$ but with the prohibition of aggressive war itself: the Preamble to the 1924 Geneva Protocol (not entered in force) ${ }^{118}$ had stated that 'a war of aggression constitutes a violation of [the international] solidarity and is an international crime'. On 24 September 1927, the Assembly of the League had declared that 'all wars of aggression are, and shall always be prohibited'. The 1928 'Briand-Kellogg Pact' ${ }^{119}$ tried to fill the gap in the LoN Covenant and to translate into law the St Augustine's and St Thomas Aquinas' doctrines on (un)just wars.

Clearly, there was a need to develop law against atrocities, as there was need for a name to qualify the Nazi 'final solution' and other previous massacres (the 'Armenian genocide'). The term 'genocide' was coined in 1944 by Raphaël Lemkin-who advocated for 


\section{Hostes humani generis: Pirates, Slavers, and Other Criminals}

the adoption of UN General Assembly Resolution 96 (I) and the 1948 Convention-and it was employed in the indictment of Hermann Göring and others on 8 October 1945.

The post-Second World War evolution was announced through the 1943 Moscow Declaration, the 1945 Potsdam Declaration and international instruments of surrender or armistices and declarations regarding these instruments, or treaties of peace. ${ }^{120}$ Articles 6 (and 1946 Protocol) and 5, respectively, of the Nuremberg ${ }^{121}$ and Tokyo ${ }^{122}$ Charters empowered the tribunals to try and punish individuals charged with war crimes, crimes against humanity, and crimes against peace. The trials before international courts and victorious powers' domestic courts in their zones of occupation in Germany-the vast majority of prosecutions, under Allied Control Council Law No 10, adopted in Berlin on 20 December 1945 123 -took place, and the general principles (p. 141) of international law recognized were affirmed by UN General Assembly's resolution 95 (I) ${ }^{124}$ and the ILC. ${ }^{125}$

\subsection{Terrorists}

Despite the widespread occurrence of terrorist acts since the 19th century, States dealt with terrorism through municipal law; the first attempt to approach it as a discrete subject matter of (criminal) international law was only in the mid-1930s.

Yet the laws and customs of war had prohibited afflicting terror on a civilian population and the Commission on Responsibilities established in 1919 reported that Germany and its allies had planned and executed a 'system of terrorism'. ${ }^{126}$ Recently, it has been determined that the acts of violence the primary purpose of which is to spread terror among the civilian population are a war crime. ${ }^{127}$

But it was the LoN which attempted to define and codify terrorism as an international crime following the assassination in Marseille, on 9 October 1934, of King Alexander I of Yugoslavia and French Foreign Affairs Minister, Louis Barthou. Not all States were convinced of the need for, or the utility of, a convention, and the LoN attempt prefigured many of the legal, political, ideological, and rhetorical disputes which would be exacerbated after the Second World War. ${ }^{128}$ Noting that 'the rules of international law concerning the repression of terrorist activity are not at present sufficiently precise to guarantee efficiently international cooperation', a resolution adopted by the Council of the LoN in 1934 established an intergovernmental expert Committee for the International Repression of Terrorism. The Committee was mandated by the Council to draft a convention to repress 'conspiracies or crimes committed with a political and terrorist purpose'129 and later, in a resolution adopted in 1936, the Assembly of the LoN stated that the convention should have 'as its principle objects', amongst others, the prohibition of any form of preparation or execution of terrorist outrages upon the life or liberty of persons taking part in the work of foreign public authorities and services and to punish terrorist outrages which 'have an (p. 142) international character'. Neither Council nor Assembly defined terrorism in their resolutions. 


\section{Hostes humani generis: Pirates, Slavers, and Other Criminals}

Based on the draft submitted by the Committee, two conventions were adopted at Geneva in 1937: ${ }^{130}$ the Convention for the Prevention and Punishment of Terrorism (requiring States to prosecute or extradite international terrorist offences, although it did not exclude the offences from the political offence exception to extradition), and the Convention for the Creation of an International Criminal Court (as an alternative to domestic courts). Although States could become parties to either convention separately, neither of them ever entered into force.

Terrorism would not reappear in international law until the 1970 s. ${ }^{131}$ It is nowadays still pending a universally accepted definition, seemingly due to a reluctance by some to criminalize (any) political resistance against forcible action which deprives peoples of their right to self-determination and freedom and independence, and by others for fear of impairing the right of asylum and refugee status.

\section{Conclusion}

Legal literature and States have built upon Cicero's legacy on pirates as hostes humani generis, extending to other acts the legal consequences attached to them (criminalization and universal jurisdiction): the slave trade or enslavement, war crimes, crimes against peace, crimes against humanity, terrorism, etc. Concepts, persons (diplomats, scholars, activists, etc.), and organizations (both intergovernmental and NGOs), and a quite 'relative normativity' (practices, treaties entered and not entered into force, public and private drafts, resolutions, declarations, etc.) are involved in the assertions of the criminal character of certain acts and the establishment of universal jurisdiction. However, international legal foundations (ranging from principles of humanity, universal morality, justice, to the laws of religion and nature, etc.) posed several questions by 1945 because of the confusion regarding the law-making and law enforcement, the lack of judicial practice, etc., even after the ICRC had managed to convince States to invert Cicero's maxim silent enim leges inter arma.

(p. 143) Piracy, slavery, and other acts or activities which are nowadays considered criminal were not necessarily considered so in other times. The theoretical distinction between piracy and privateering blurred in practice, and the interaction and confusion between municipal laws and the law of nations were commonplace where States' contradictory interests and perceptions of reality met. Hence, to find a clear internationally relevant practice-in the absence of an international treaty-turned out anything but easy.

There have been a number of 'positive' international data endorsing the prohibition of the slave trade and enslavement or the laws and customs of war. Yet it is difficult-if not impossible-to find judicial practice before 1945. Curiously, the resort to the 'piracy analogy' and the clause 'as if for an act of piracy' gives rise to two remarks. First, being included in international treaties, those provisions are some of the clearest and more explicit (although indirect) historical recognition by States of piracy as an international crime subject to universal jurisdiction. Second, prohibiting acts did not always mean criminalizing them, extending States' jurisdiction, and punishing perpetrators. The 'piracy analogy' 
proved the willingness of States to accept (regarding violations of laws and customs of war at sea) or to reject (regarding slave-trade at sea, as concerned the right to seize) subjecting the suppression of these acts to universal jurisdiction.

Whether one adheres to a 'positivist' or a 'naturalist' understanding of international law conditions the determinations concerning the existence and definition of an international crime, and the title or basis of State's jurisdiction to prosecute and punish criminals; namely, bearing in mind a necessary balance between substantive justice and legality. No less important than determination on the matter, mainly from a historical perspective, is the 'critical date' from when one may assert that there has been an international crime, and eventually a crime subject to universal jurisdiction. Regarding the law of piracy, it has been said that

[a]s a practical matter ... a competent lawyer can construct a model of reality using legal words that will seem to justify whatever a statesmen thinks is in the political interest of his state. But under 'naturalist' theory, that justification is merely an argument with which others, believing themselves more attune to the eternal rules of morality and 'true law', can disagree. Under 'positivist' theory, no state has the legal power to determine rules of international law, but only the power to interpret those rules for itself and try to convince others that that interpretation is correct. ... The arguments among lawyers and policy-makers about these matters are endless ... [but] the 'victory' for the most articulate naturalist model builders resulted in a meaningless codification of no law. ${ }^{132}$

International law provided arguments and legal foundations to address the repression of pirates, slavers, and other criminals before 1945, yet law-enforcement practice also offered arguments to prevent their criminal prosecution on a universal jurisdiction basis. Law as usual.

\section{Bibliography}

\section{Recommended Reading}

Allain, Jean The Slavery Conventions. The Travaux Préparatoires of the 1926 League of Nations Convention and the 1956 United Nations Convention (Martinus Nijhoff Publishers Leiden 2008).

Azcárraga y Bustamante, José Luis de El corso marítimo (CSIC Instituto 'Francisco de Vitoria’ Madrid 1950).

Bush, Jonathan A “"The Supreme ... Crime” and Its Origins: The Lost Legislative History of the Crime of Aggressive War' (2002) 102 Columbia Law Review 2324-69.

Dubner, Barry H The Law of International Sea Piracy (Martinus Nijhoff Publishers The Hague 1980). 
Graven, Jean 'Le crimes contre l’humanité' (1950) 76 Recueil des cours 427-608.

Greppi, Edoardo 'The Evolution of Individual Criminal Responsibility under International Law' (1999) 81 International Review of the Red Cross 531-3.

Piggott, Francis Taylor The Declaration of Paris 1856: A Study (University of London Press London 1919).

Rubin, Alfred P The Law of Piracy (2nd edn Transnational Publishers Irvington-on-Hudson NY 1998).

Schwelb, Egon 'Crimes Against Humanity' (1946) 23 British Yearbook of International Law 178-226.

Sottile, Antoine 'Le terrorisme international' (1938) 65 Recueil des cours 87-184.

Vabres, H Donnedieu de 'La répression internationale du terrorisme: Les Conventions de Genève (16 novembre 1937)' (1938) 62 Revue de droit international et législation comparée 37-74.

\section{Notes:}

(1) Cicero used the phrase 'communis hostis omnium' in his De Officiis III, 29 and in Contra Verres II, iv, 21 (cf AP Rubin The Law of Piracy (2nd edn Transnational Publishers Irvington-on-Hudson NY 1998) at 5 fn 19 and 17 fn 61).

(2) Rome Statute of the International Criminal Court (adopted 17 July 1998, entered into force 1 July 2002) 2187 UNTS 90, art 7.

(3) H Grotius De jure belli ac pacis (1625) vol 2, ch 20, para 40.

(4) A Cassese International Criminal Law (OUP Oxford 2003) at 72.

(5) 'Draft Convention on the Competence of Courts in Regard to Foreign States: Part IVPiracy' (1932) 26 American Journal of International Law Supplement: Research in International Law 739-885 at 754; The Law of Piracy (n 1) 335-45 and 360.

(6) J Allain The Slavery Conventions. The Travaux Préparatoires of the 1926 League of Nations Convention and the 1956 United Nations Convention (Martinus Nijhoff Publishers Leiden 2008) at 129.

(7) WR Riddell 'Observations on Slavery and Privateering' (1930) 15 The Journal of Negro History 337-71.

(8) WG Grewe The Epochs of International Law (M Byers trans) (de Gruyter Berlin 2000) at 554-69.

(9) Le Louis (1817) 12 Dods 210, 165 ER 1464; and The Antelope 23 US 66, 10 Wheat 66 (1825). 
(10) JL Brierly The Law of Nations (CHM Waldock ed) (6th edn Clarendon Press Oxford 1963) at 307.

(11) 'Articles of the Draft Code of Crimes against the Peace and Security of

Mankind' (1996-II) Yearbook of the International Law Commission 17-42 at 29.

(12) See Section 2.1.3.

(13) For instance, E McWhinney Aerial Piracy and International Terrorism (Martinus Nijhoff Publishers Dordrecht 1971); Air Piracy 49 USC App § 1472(n)(1988); and United States v Fawaz Yunis 681 F Supp 896 (DDC 1988) and 924 F 2d 1086 (DC Cir 1991).

(14) I Shearer 'Piracy' in R Wolfrum (ed) The Max Planck Encyclopedia of Public International Law (OUP Oxford 2008) at <www.mpepil.com>.

(15) JL de Azcárraga y de Bustamante El corso marítimo (CSIC-Instituto 'Francisco de Vitoria' Madrid 1950).

(16) Because proposals to define piracy referred to '[a]ny "illegal” act ...', AP Rubin still wondered in 1976 whether piracy was illegal. AP Rubin 'Is Piracy Illegal?' (1976) 70 American Journal of International Law 92-5.

(17) $R$ v Joseph Dawson (1696) 13 Howell's St Tr 451.

(18) United States $v$ Smith 18 US 153, 5 Wheat 153 (1820) at 161. See also The Magellan Pirates (1853) 1 Sp Ecc \& Ad 81, 164 ER 47, cited in The Law of Nations (n 10) 307 and fn 3.

(19) Notwithstanding The Law of Piracy (n 1) 61-70.

(20) Declaration Respecting Maritime Law (signed 16 April 1856) (1856) 115 CTS 1.

(21) While the Declaration (ibid) advocated protecting all civilian property on the high seas, the US Constitution lists issuing letters of marque as a power of the Congress (art 1, s 8, cl 10).

(22) Hague Convention (IV) Concerning the Laws and Customs of War on Land (opened for signature 18 October 1907, entered into force 26 January 1910) (1907) 205 CTS 277.

(23) 'The Oxford Manual of Naval War' in JB Scott (ed) Resolutions of the Institute of International Law (OUP New York 1916) 174-201.

(24) 'A Treaty between the Same Powers, in Relation to the Use of Submarines and Noxious Gases in Warfare' (1922) 16 American Journal of International Law Supplement: Official Documents 57-60, art 3.

(25) The Nyon Arrangement, with Annexes and Map (signed 14 September 1937) 181 LNTS 137. 
(26) ibid.

(27) GA Finch 'Piracy in the Mediterranean' (1937) 31 American Journal of International Law 659-65; R Genet 'The Charge of Piracy in the Spanish Civil War' (1938) 30 American Journal of International Law 253-63.

(28) See proceedings in LN Doc C/196/M/70/1927/V, at 116.

(29) The 'questionnaire' is reproduced in 'Questionnaire No. 6: Piracy' (1926) 20 American Journal of International Law Supplement 222-9; the analysis of the States' replies in 'Legal Status of Government Ships Employed in Commerce' (1926) 20 American Journal of International Law Supplement 260-78 at 273. The reply of Romania was written by V Pella, who took the opportunity to give the course 'La répression de la piraterie' (1926) 15 Recueil des Cours de l’Académie de Droit International de La Haye 145-268.

(30) ED Dickinson 'The Questionnaire on Piracy' (1926) 20 American Journal of International Law 750-2.

(31) Convention on the High Seas (signed 29 April 1958, entered into force 30 September 1962) 450 UNTS 82 , arts 14-21.

(32) United Nations Convention on the Law of the Sea (signed 10 December 1982, entered into force 16 November 1994) 1833 UNTS 397, arts 100-7.

(33) 'Report of the International Law Commission Covering the Work of its Eighth Session, 23 April-4 July 1956’ (1956-II) Yearbook of the International Law Commission 253302 at 282 .

(34) BH Dubner The Law of International Sea Piracy (Martinus Nijhoff Publishers The Hague 1980) at 37-102.

(35) See the appendix (pt V) to the Harvard Draft Convention: S Morrison (ed) 'Part V: A Collection of Piracy Laws of Various Countries' (1932) 26 American Journal of International Law Supplement: Research in International Law 887-1013.

(36) The Law of Nations (n 10) 154. The definition of piracy in the sixth edition of Brierly's Law of Nations, of 1963, was rewritten (by Waldock) to accommodate to the definition contained in the 1958 Convention.

(37) It has been adjudicated that a frustrated attempt to commit a piratical robbery is equally piracy according to international law (In re Piracy jure gentium [1934] AC 586 (LR PC)).

(38) See H Lauterpacht 'Insurrection et piraterie' (1939) 46 Revue Générale de Droit International Public 513-49; and the debate in the ILC (Report of the International Law Commission (n 33)). 
(39) For instance, Dickinson's critique of 'Matsuda report': The Questionnaire on Piracy (n 30).

(40) WB Lawrence Wheaton's Elements of International Law (6th edn Little, Brown and Company Boston MA 1857) 184-6. See also The Law of Nations (n 10) 154.

(41) The Law of Piracy (n 1) 343.

(42) CP Anderson 'As if for an Act of Piracy' (1922) 16 American Journal of International Law 260-1.

(43) Report of the International Law Commission (n 33).

(44) Draft Convention on Piracy (n 5) arts 2 and 6 and the respective comments.

(45) ibid art 12 and the comment.

(46) ibid art 7 and the comment; see also El corso marítimo (n 15) 130.

(47) Draft Convention on Piracy (n 5) arts 8-11 and the respective comments.

(48) ibid arts 14 and 15 and the respective comments.

(49) See the contribution by S Drescher and P Finkelman 'Slavery' in this volume.

(50) Somerset v Stewart (1772) Lofft 1, 98 ER 499.

(51) For a background, AM Trebilcock 'Slavery' in R Bernhardt (ed) Encyclopedia of Public International Law (North-Holland Elsevier 2000) vol 4, 422-6.

(52) Slavery Convention (signed 25 September 1926, entered into force 9 March 1927) 60 LNTS 253.

(53) Confronting enslavement and sexual slavery during Second World War accusations, Japan has argued that there was no customary law against slavery then; UN Commission on Human Rights (Sub-Commission) 'Systematic Rape, Sexual Slavery and Slavery-like Practices during Armed Conflict: Final Report Submitted by Gay J. McDougall, Special Rapporteur' (22 June 1998) UN Doc. E/CN.4/Sub.2/1998/13, para 4.

(54) Declaration of the Eight Powers relative to the Universal Abolition of Slave Trade, annexed as Act XV to the 1815 General Treaty of the Vienna Congress (signed 8 February 1815) (1815) 63 CTS 473. The signatory States were Austria, France, Great Britain, Portugal, Prussia, Russia, Spain, and Sweden; all of them, except Spain, secretly signed the Treaty of Paris of 30 May 1814, where France and Great Britain pledged to abolish the slave-trade.

(55) Treaty of Peace and Amity (signed 18 February 1815) (1815) 12 TIAS 47.

(56) Portugal, Spain and Sweden were absent in the Congress of Verona (1822). 
(57) Treaty for the Suppression of the African Slave-Trade (signed 20 December 1841) (1841) 73 CTS 32.

(58) ibid arts I, III, and X.

(59) ibid arts VI, VII, X, and annex B.

(60) ibid art XV.

(61) The act is reproduced in 'General Act of the Conference of Berlin Concerning the Congo' (1909) 3 American Journal of International Law Supplement: Official Documents $7-25$.

(62) ibid art 9.

(63) Declaration Relative to the Liberty of Commerce in the Basin of the Congo, its Embouchures and Neighbouring Country, and Dispositions Connected Therewith, attached to the General Act (art 6).

(64) General Act of the Brussels Conference Relating to the African Slave Trade (signed 2 July 1890, entered into force 31 August 1891) (1890) 173 CTS 293.

(65) Convention Revising the Berlin and Brussels Acts (signed 10 September 1919) (1919) 225 CTS 500. The United States never ratified the 1919 Convention.

(66) ibid art 11.

(67) International Agreement for the Suppression of the White Slave Traffic (signed 18 May 1904) 1 LNTS 83; 195 CTS 326.

(68) International Convention for the Suppression of White Slave Traffic (signed 4 May 1910, entered into force 14 August 1951) (1910) 211 CTS 45.

(69) ibid arts 1-3.

(70) ibid arts 6 and 7.

(71) ibid arts 1-3, art 5 and the Final Protocol.

(72) International Convention for the Suppression of the Traffic in Women and Children (signed 30 September 1921) 9 LNTS 415.

(73) ibid arts 2-4.

(74) International Convention for the Suppression of the Traffic in Women of Full Age (signed 11 October 1933) 150 LNTS 431.

(75) arts 1-3. 
(76) The 1921 and 1933 Conventions: Protocol to Amend the Convention for the Suppression of the Traffic in Women and Children and the Convention for the Suppression of the Traffic in Women of Full Age (signed 12 November 1947) 53 UNTS 13; International Convention for the Suppression of the Traffic in Women and Children Amended by the Protocol (signed 12 November 1947) 59 UNTS 39; and International Convention for the Suppression of the Traffic in Women of Full Age Amended by the Protocol (signed 12 November 1947) 53 UNTS 49.

(77) The 1904 and 1910 Conventions: International Agreement for the Suppression of the White Slave Traffic Amended by the Protocol (signed 4 May 1949) 92 UNTS 19; International Convention for the Suppression of the White Slave Traffic Amended by the Protocol (signed 4 May 1949) 98 UNTS 101.

(78) Approved by General Assembly resolution 317 (IV) of 2 December 1949: Convention for the Suppression of Traffic in Persons and of the Exploitation of the Prostitution of Others (entered into force 25 July 1951) 96 UNTS 271.

(79) International Convention for the Abolition of Slavery and the Slave Trade (signed 25 September 1926, entered into force 9 March 1927) 60 LNTS 253. The 1953 Protocol brought the Convention into the UN system (Protocol Amending the Slavery Convention (entered into force 7 December 1953) 182 UNTS 51); yet there are States which have consented to the 1926 Slavery Convention but not to the 1953 Protocol.

(80) Convention for the Abolition of Slavery and the Slave Trade (n 79) arts 2 and 3.

(81) ibid art 4. This general obligation was never concretize in specific bilateral or multilateral agreements.

(82) ibid art 6.

(83) ibid art 7.

(84) ibid art 1.

(85) ibid Preamble and art 5.

(86) Convention Concerning Forced or Compulsory Labour (ILO No 29) (adopted 28 June 1930, entered into force 1 May 1932) 39 UNTS 55. The 1930 Convention-which gathers many of the principles and limitations announced in the '1928 Bellot Rules', adopted by the ILA in Warsaw-was modified in 1946 and complemented in 1957.

(87) Supplementary Convention on the Abolition of Slavery, the Slave Trade, and Institutions and Practices Similar to Slavery (signed 7 September 1956, entered into force 30 April 1957) 226 UNTS 3.

(88) ibid arts 3, 5, and 6.

(89) ibid art 1. 
(90) If not covered by the 1926 Convention (n 79), the 1956 Convention (n 87) considers the victim as a 'person of servile status' (art 7(b)), but not a 'slave' (art 7(a)).

(91) Such as, inter alia, the traffic in persons and the exploitation of the prostitution of others, 1949 UN Convention (n 78); or trafficking in persons, especially women and children, and the smuggling of migrants, Protocols Supplementary to the Convention against Transnational Organized Crime (adopted 15 November 2000, entered into force 29 September 2003) 2225 UNTS 209.

(92) However, the definition of 'slave-trade' (art 7(c)) differs in an insignificant manner from the definition found in the 1926 Convention (n 79).

(93) The definition of 'enslavement' (not of 'slavery') contained in the art 7.2(c) is identical to that of slavery in the 1926 Convention (n 79), but includes the exercise of the powers attaching to the right of ownership 'in the course of trafficking in persons, in particular women and children'.

(94) See J Hathaway 'The Human Rights Quagmire of “Human Trafficking”' (2008) 49 Virginia Journal of International Law 1-59; and AT Gallagher 'Human Rights and Human Trafficking: Quagmire or Firm Ground? A Response to James Hathaway' (2008) 49 Virginia Journal of International Law 789-848.

(95) Namely, the 'colonial clause' (art 9); it is noticeable the different wording of art 12 of the 1956 Convention (n 87).

(96) The proposal of 1956 Drafting Committee of the ILC concerning the regime of the high seas influenced the drafting of the 1956 Convention (n 87).

(97) Hague Convention Concerning the Laws and Customs of War on Land (adopted 29 July 1899, entered into force 4 September 1900) (1899) 187 CTS 429.

(98) Hague Convention (IV) Concerning the Laws and Customs of War on Land (n 22).

(99) arts 6, 44, and 52 of the 1899 Hague Convention (n 97), and arts 1, 6, 46, and 52 of the 1907 Hague Convention (IV) (n 22).

(100) Convention Relative to the Treatment of Prisoners of War (adopted 27 July 1929, entered into force 19 June 1931) 118 LNTS 343; arts 30-1 deal with forced labour from POWs.

(101) This is the meaning of the Declaration of the US State Department in 1941 concerning the Japanese-Americans interned in the US; CH Rosenberg 'International Law Concerning Accidents to War Prisoners Employed in Private Enterprises' (1942) 36 American Journal of International Law 294-8 at 298.

(102) art 6 of the Charter of the [Nuremberg] International Military Tribunal (signed and entered into force 8 August 1945) 82 UNTS 279; see also art 5 of the Charter of the Inter- 
national Military Tribunal for the Far East (signed and entered into force 19 January 1946) 4 Bevans 20.

(103) The circumstantial evidence were the propositions in which art 3 of the 1922 Treaty of Washington (n 24) was based.

(104) Geneva Convention for the Amelioration of the Condition of the Wounded and Sick in Armed Forces in the Field (signed 12 August 1949, entered into force 21 October 1950) 75 UNTS 31; Geneva Convention for the Amelioration of the Condition of the Wounded, Sick and Shipwrecked Members of Armed Forces at Sea (signed 12 August 1949, entered into force 21 October 1950) 75 UNTS 85; Geneva Convention Relative to the Treatment of Prisoners of War (signed 12 August 1949, entered into force 21 October 1950) 75 UNTS 135; Geneva Convention Relative to the Protection of Civilian Persons in Time of War (signed 12 August 1949, entered into force 21 October 1950) 75 UNTS 287; Protocol Additional to the Geneva Conventions of 12 August 1949, and Relating to the Protection of Victims of International Armed Conflicts (Protocol I) (adopted 8 June 1977, entered into force 7 December 1978) 1125 UNTS 3; and Protocol Additional to the Geneva Conventions of 12 August 1949, and Relating to the Protection of Victims of Non-international Armed Conflicts (Protocol II) (adopted 8 June 1977, entered into force 7 December 1978) 1125 UNTS 609.

(105) Convention on the Non-Applicability of Statutory Limitations to War Crimes and Crimes against Humanity (adopted 26 November 1968, entered into force 11 November 1970) 754 UNTS 73.

(106) arts 7 and 8.

(107) 'Formulation of the Nürnberg Principles' (1950-II) Yearbook of the International Law Commission 374-8.

(108) For example, the ECHR (Judgment of 26 July 2005, Siliadin v France (2006) 43 EHRR 16, para 122) and the ICTY (Prosecutor v Dragoljub Kunarac, Radomir Kovac and Zoran Vukovic (Judgment) ICTY-96-23-T \& ICTY-96-23/1-T (22 February 2001) para 539 and passim; and Prosecutor v Dragoljub Kunarac, Radomir Kovac and Zoran Vukovic (Judgment) ICTY-96-23-T \& ICTY-96-23/1-A (12 June 2002) paras 117-19; also Prosecutor v Milorad Krnojelac (Judgment) IT-97-25-T (15 March 2001) at 353 and fns 955-7).

(109) G Schwarzenberger International Law as Applied By International Courts and Tribunals (Stevens \& Sons London 1968) vol 2 (The Law Of Armed Conflict), at 462-6; E Greppi 'The Evolution of Individual Criminal Responsibility under International Law' (1999) 81 International Review of the Red Cross 531-53.

(110) Geneva Convention for the Amelioration of the Treatment of Wounded in the Field (adopted 22 August 1864, entered into force 22 June 1865) (1864) 129 CTS 361. 
(111) Convention for the Amelioration of the Condition of the Wounded and Sick in Armies in the Field (entered into force 9 August 1907, no longer in force) 11 LNTS 440; and Convention for the Amelioration of the Condition of the Wounded and Sick in Armies in the Field (entered into force 19 June 1931) 118 LNTS 303.

(112) CK Hall 'The First Proposal for a Permanent International Criminal Court' (1998) 38 International Review of the Red Cross 57-74.

(113) These principles found still expression in art 3 of the ICTY Statute.

(114) Convention Relative to the Treatment of Prisoners of War (n 100).

(115) France, Great Britain and Russia Joint Declaration of 24 May 1915 (Record Group, US National Archives, Papers relating to the Foreign Relations of the US, No 59, 867.4016/67).

(116) Treaty of Peace at Versailles (adopted 28 June 1919, entered into force 10 January 1920) (1919) 225 CTS 188.

(117) See the Treaty of Washington (n 24); also J-M Henckaerts and L Doswald-Beck (eds) Customary International Humanitarian Law (CUP Cambridge 2005) vol 1 (Rules), rule 151.

(118) Reprinted in 'Protocol for the Pacific Settlement of International Disputes' (1925) 19 American Journal of International Law Supplement: Official Documents 9-17 at 9.

(119) General Treaty for the Renunciation of War or the World Peace Act (signed 27 August 1928, entered into force 24 July 1929) 94 LNTS 57.

(120) All reprinted in (1948) 42 American Journal of International Law Supplement: Official Documents: 'Allied and Associated Powers and Italy: Treaty of Peace' 47-177; 'Treaty of Peace with Roumania' 252-77; 'Treaty of Peace with Hungary' 225-51; 'Treaty of Peace with Bulgaria' 179-202; and 'Treaty of Peace with Finland' 203-23.

(121) Charter of the [Nuremberg] International Military Tribunal (n 102).

(122) Charter of the International Military Tribunal for the Far East (n 102).

(123) Allied Control Council Law No 10: Punishment of Persons Guilty of War Crimes, Crimes Against Peace and Against Humanity (20 December 1945) 3 Official Gazette of the Control Council for Germany (31 January 1946) 50-5.

(124) UNGA Res 95 (I) (11 December 1946) UN Doc A/RES/1/95.

(125) UN ILC ‘Principles of International Law Recognized in the Charter of the Nürnberg Tribunal and in the Judgment of the Tribunal, with Commentaries' (1950-II) Yearbook of the International Law Commission 274-8. 
(126) 'Commission on the Responsibility of the Authors of the War and on Enforcement of Penalties' (January-April 1920) 14 American Journal of International Law 95-154 at 113.

(127) Prosecutor v Stanislav Galić (Judgment) ICTY-98-29-T (5 December 2003) para 70.

(128) B Saul 'The Legal Response of the League of Nations to Terrorism' (2006) 4 Journal of International Criminal Justice 78-102.

(129) Sixth Meeting (Public) of the Eighty-Third Session of the Council (1934) 15 League of Nations Official Journal 1758-60 at 1760.

(130) Reproduced in LN International Conference Proceedings on the Repression of Terrorism, Geneva (1-16 November 1937) LN Doc C/94/M/47/1938/V (LN Archives Geneva: Council Members Docs) vol 1103, Annex I, at 5 and 19.

(131) There was a soviet tentative to introduce terrorism in the Nuremberg Charter (n 102), and terrorism was incorporated in the 1954 ILC's 'Draft Code of Offences against the Peace and Security of Mankind' (1954-II) Yearbook of the International Law Commission 112-22; later in the draft art 5 of the 'Report of the Preparatory Committee on the Establishment of an International Criminal Court' UN Diplomatic Conference of Plenipotentiaries on the Establishment of an International Criminal Court (Rome 15 June-17 July 1998) (14 April 1998) UN Doc A/CONF.183/2/Add.1.

(132) The Law of Piracy (n 1) 310-11.

\section{Joaquín Alcaide Fernández}

Joaquín Alcaide Fernández is Professor of Public International Law and International Relations at University of Seville (Spain). He has published extensively on terrorism, human rights and humanitarian law, State and criminal responsibility, peace and security, law of the sea and environment. 